\title{
INTEGRATED DIGITAL PLATFORM FOR THE VALORIZATION OF A CULTURAL LANDSCAPE
}

\author{
L. M. Angheluță ${ }^{\text {a*, L. Ratoiua }}$, A. I. Chelmus ${ }^{\mathrm{a}}$, R. Rădvan ${ }^{\text {a }}$, A. Petculescu ${ }^{\mathrm{b}}$ \\ ${ }^{a}$ National Institute for Research and Development in Optoelectronics INOE 2000 - (laurentiu, lucian, radvan)@inoe.ro \\ b “Emil Racoviță” Institute of Speleology - alexpet@gmail.com
}

KEY WORDS: rupestral cave, GIS, airborne survey, photogrammetry, cultural heritage, natural heritage, cultural landscape

\begin{abstract}
:
This paper presents a newly started demonstrative project regarding the implementation and validation of an interdisciplinary research model for the Aluniș-Bozioru (Romania) cultural landscape, with the development of an online interactive digital product. This digital product would provide complementary data about the historical monuments and their environment, and also, constant updates and statistical comparison in order to generate an accurate evaluation of the state of conservation for this specific cultural landscape. Furthermore, the resulted information will contribute in the decision making process for the regional development policies. The project is developed by an interdisciplinary joint team of researchers consisted of technical scientists with great experience in advanced non-invasive characterization of the cultural heritage (NIRD for Optoelectronics - INOE 2000) and a group of experts from geology and biology (Romanian Academy's "Emil Racoviță" Institute of Speleology - ISER). Resulted scientific data will include: 3D digital models of the selected historical monuments, microclimate monitoring, Ground Penetrating Radar survey, airborne LIDAR, multispectral and thermal imaging, soil and rock characterization, environmental studies. This digital product is constituted by an intuitive website with a database that allows data corroboration, visualization and comparison of the 3D digital models, as well as a digital mapping in the GIS system.
\end{abstract}

\section{INTRODUCTION}

This paper presents a new project that aims to contribute to the establishing of a scientific strategy for the conservation of a cultural landscape. Based on the experience with developing preventive conservation programs for the somehow similar case of cultural heritage in museums and historical monuments, and on the corroborated research activities proposed in this project we want to bring a better understanding to the concept of cultural landscape.

A wide range of aggressive factors and threats, both natural (air pollution, extreme weather, microbiological, landslides and collapses) and anthropogenic (logging, overgrazing, gravel pits, population and visitors etc.) makes the heritage sites vulnerable by inducing stress to the soil, cultural heritage assets, vegetation, biota and even the population and the visitors themselves. This requires a call for action in order to determine a instability limit for the cultural landscape reversible modifications.

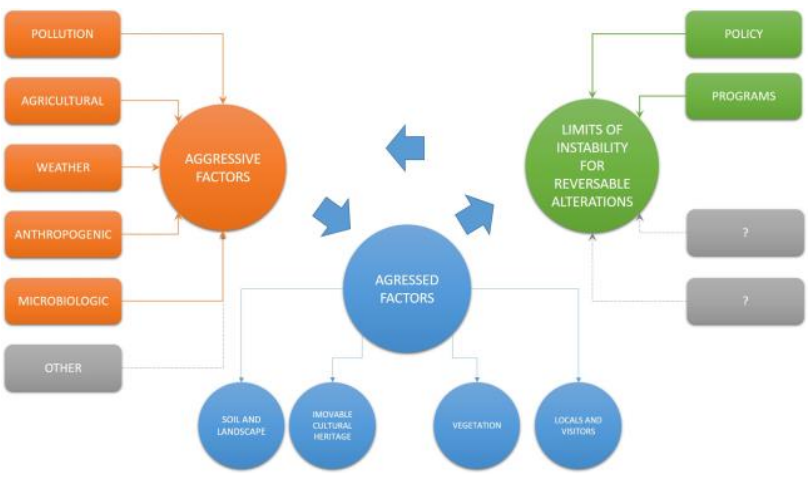

Figure 1 Agents involved in cultural landscape preventive conservation
The mean of achieving the proposed goal is to develop an integrated digital platform that will serve as an online instrument for corroborating two different areas of research. The results of coordinated investigation and monitoring campaigns in the case study area will be managed and stored in a dedicated database that will also serve as source for the proposed online instrument.

According to UNESCO (WHC, 1992), a cultural landscape designates the "combined works of nature and of man". This project's case study consists in: the Rupestral Assembly from Aluniș (LMH, 2014) and, as part of The Rupestral Assembly of Bozioru Mountains (LMH, 2014), the following monuments: Fundătura (LMH, 2014), Fundul Peșterii (LMH, 2014), Piatra lui Iosif (LMH, 2014) and Agatonul Nou (LMH, 2014), focusing the research on an associative cultural landscape (WCH, 2008), a specific but less studied category. These last mentioned monuments refer to isolated religious and cultural traces of Hesychasts tradition, dwellings of hermits secluded in the mountains. Their cultural expression indicates a characteristic type of relation between the built and the natural heritage. Comparing to UNESCO World Heritage List, a similar case is represented by The Rock-Hewn Churches of Ivanovo from Bulgaria (UNESCO World Heritage List, 1979).

Following the guidelines of the Faro Convention from 2005 (Council of Europe, 2005) the results of this proposed project will contribute to the valorisation process of the reciprocal relationships between the built heritage and its natural environment surroundings.

As a natural continuity of the National Institute for Research \& Development in Optoelectronics INOE 2000 previous projects and collaborations, this project follows a unified envisioned 
model of good practice and data management for cultural heritage conservation studies.

\section{CASUISTRY}

The selected monuments for this project are just a few from a greater number of similar monuments in the Buzău Mountains. The proposed integrated online digital model of corroborated data that characterizes a cultural landscape will be implemented and tested for these five monuments in order to demonstrate the applicability for the similar monuments in the region.

The rupestral settlements in this area have been brought to light for the first time by the end of XIX century (Odobescu in 1871 and Bazil Iorgulescu in 1892). But only after 1971 detailed researches about their history, archaeology, ethnography or folklore have been conducted, and by 1980 new rupestral caves were being discovered reaching a total number of 29 . Until these first serious studies it was generally accepted that these caves have been used in medieval times due to the remaining documents of that time and the chirilic inscriptions on their walls. These studies concluded that many of these caves have been carved and used long before the medieval times some of them going back to the Hallstatt period.

In the following we will make a brief introduction of the five monuments.

\subsection{Alunis rupestral complex}

This is the largest complex and is dated in 400-600 AD. It has 4 main areas and one of them (Alunis A) is used today as a church. The walls are covered in carvings with Malta crosses and chirilic inscriptions of years in the Julian Calendar system (oldest being 1548) and names.

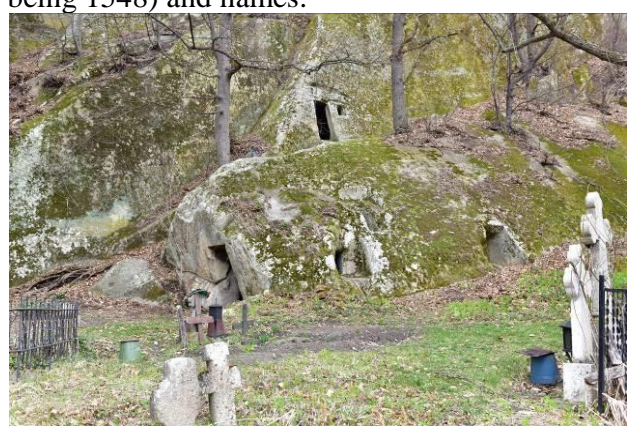

Figure 2 Rupestral complex from Alunis

\subsection{Fundătura}

This monument is mentioned in a 1678 document as a place of worship. There are no other elements for an earlier dating. This place was carved in an isolated rectangular rock with an entrance and several windows. There are still visible signs of the carving in the stone as well as some old inscriptions.

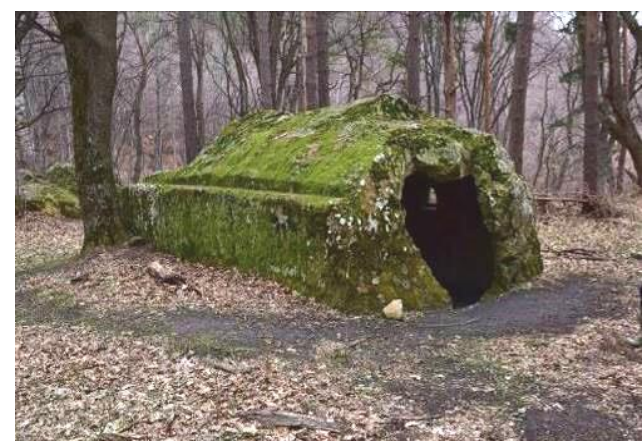

Figure 3 Fundătura, carved in an isolated rectangular rock

\subsection{Fundul Peșterii}

Perhaps the oldest monument from the whole series in the area is this small cave (Figure 3). Archaeological surveys and mural inscriptions determined the researchers to identify two distinct usage periods: late Hallstatt (600-400 BC) and the second in the late medieval times. The walls have carvings representing dagger-swords (akinakai) and arrow heads dating back in the late Iron Age (Constantin Buzdugan, 1976).

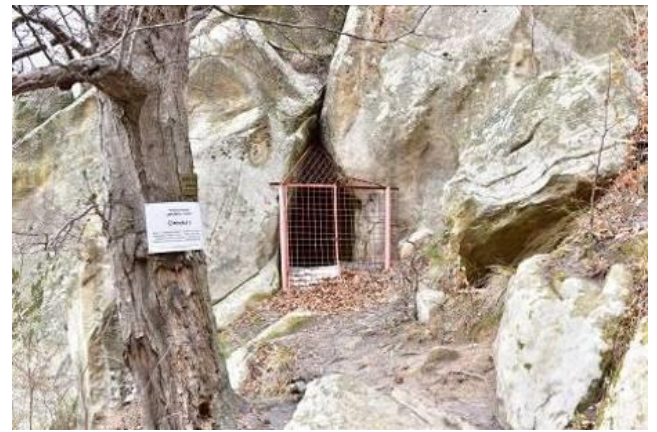

Figure 4 Carvings on the walls of this cave indicate an early use by the end of Hallstatt era

\subsection{Piatra lui Iosif (Joseph's stone)}

This settlement was dated as 300-600 AD based on specific carved symbol (the fish) associated with paleo-Christianity period, also found on other monuments from the same period in Transylvania.

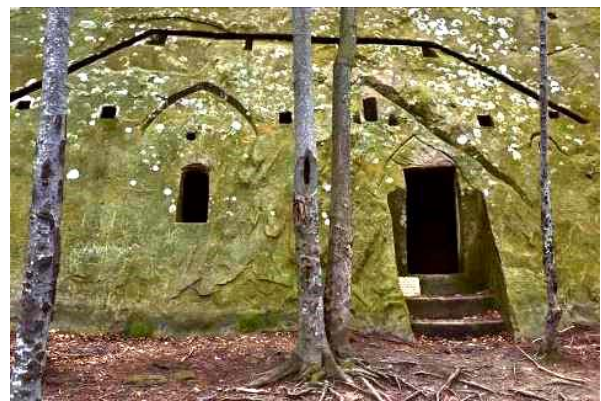

Figure 5 Piatra lui Iosif ("Joseph's Stone/Church") carved in the mountain

\subsection{Agatonul Nou}

Was carved in a rock at the edge of a 40-50m high slope. Inscriptions and other elements cannot place this settlement earlier than the XVIIIth century.Until the 80's three of the four chambers were still whole but since then the rooftop has crumbled. 


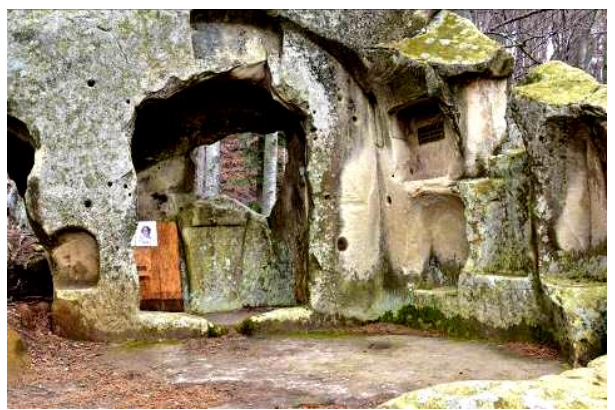

Figure 6 Ruins of the "Agatonul Nou"

\section{INVESTIGATION METHODS}

As mentioned, the goal of the project is to elaborate a joint research model for a cultural landscape by bringing together experts coming from different fields: biology, geology, speleology, restorers and cultural heritage investigators. The proposed strategy revolves around the natural and the cultural heritage characterization of these monuments' areal with specific investigation and monitoring methods.

The project activities are scheduled in monthly field campaigns for the assessment of the natural habitat and cold/warm season longer field campaigns for the investigation with specific methods of the cultural heritage assets. All these actions will be supervised by authorized personnel from the Ministry of Culture.

\subsection{Cultural heritage investigations}

As in all other previous projects, the field investigation campaign will benefit the mobile infrastructure of the ART4ART mobile laboratory. This practice has direct benefits for both the investigated cultural heritage assets and the quality of the data gathered. The mobile laboratory is designed to be modular with interchangeable investigation / monitoring / intervention methods depending on the project casuistry (Simileanu et all, 2008). In this case where the subjects are immovable the deployment of the investigation setups on site are most recommended. This way there will be no need for sampling or other invasive investigation methods.

As part of our model of good practice in artwork and monuments investigation one of the first steps is to setup an intelligent micro-climate monitoring sensor network (Moldovan, 2012). In this case, the areas to be monitored are in the mountains and with no security with a great flux of visitors. So small data logging sensors seems to be the right approach in order to be able to place them in secure positions and in some cases to double them.

An important element in our investigation model is the detailed 3D documentation of the subjects. The mobile laboratory can provide this type of documentation with either 3D laser scanning technique or photogrammetry, or both when is the case. Given the circumstances of the target locations, the 3D laser scanner would not be an optimal solution due to the difficulty of the access and the small areas for manoeuvre around the monuments. Photogrammetry will be realized with a high resolution camera (36 megapixels) and the resulted models precision matches with the $3 \mathrm{D}$ laser scanning techniques and will benefit of the photo realistic textures. The carved inscriptions will be documented this way for the first time.
Some of the monuments are recommended for georadar survey following suspicions and information that there is a possibility of unknown underground rooms/caves. Ground penetrating radar (GPR) uses electromagnetic pulse from UHF-VHF domain, which are directed into the ground and records the reflected signal. The reflections come from the discontinuity of the dielectric constant, discontinuity that is represented by a buried object, interface between two different ground layers, a void, a cave, a tunnel, mines, graves, or much other nonhomogeneity.

Each of these monuments a surrounding perimeter will be defined in GPS coordinates and those areas will be subjected to airborne survey. The UAV that is also part of the ART4ART mobile laboratory is a scientific vessel that can be equipped, separately, with 4 imaging sensors: photo camera for aerial photogrammetry, thermal camera, multispectral camera and a LIDAR system. Although due to the mountainous relief it will be difficult to accomplish, we want to map the defined perimeters with these types of imaging.

These are the main investigation directions. But usually on field new questions will come up and complementary methods like physico-chemical investigation devices (portable XRF) or digital microscopy may prove quite useful.

\subsection{Natural heritage studies}

The main geological structure - the Tarcău Nappe (Mutihac et al., 2004; Roban \& Andrăşanu, 2010) - is represented by flysch deposits, widely outcropping across the region: sandstones and microconglomerates, interbedded with marls, marly limestones and clays.. The geological studies will include:

a. field investigations of the lithostratigraphic and microtectonic features of the area (with geological compasses, using the dip and strike method, geological maps and GPS devices)

b. sedimentological logging and sampling

c. laboratory analyses - grain size, by vibrating sieving, and petrographic microscopy on thin sections.

The present-day vulnerability of the area to slope processes will be assessed by field geomorphological studies.

The geological and the climate evolution of the Carpathians, influenced from south-east, have led to a remarkable biodiversity (35\% of the bird species recorded from Romania), including species of community interest for the Natura 2000 network (Munteanu et al., 2002). Although there are studies dealing with the biota of the Buzău County within areas close to the Aluniş-Bozioru region, none of them specifically covers the sites we intent to study.

\section{INSTRUMENT DESCRIPTION}

The main purpose of the project is to develop an integrated digital platform for two different types of research data regarding historical monuments and their natural environment, in order to contribute to a model of characterizing a cultural landscape. The proposed digital platform will be designed as an online instrument in a website format with a database and online ArcGIS support (Figure 6). 


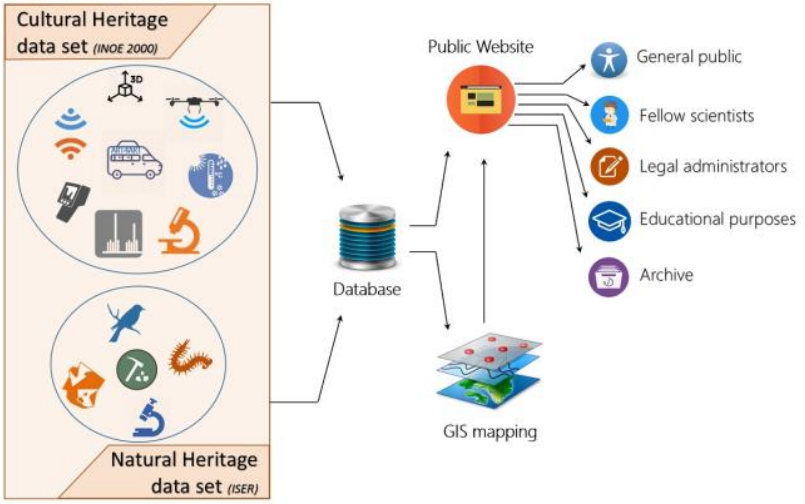

Figure 7 Proposed online tool structure

This tool will allow the input of different types of data coming from two separate fields and is meant to be an adaptable demonstrative model for the characterization of similar casuistry even with a different multidisciplinary research approach. One of the features of this instrument are the online collaborative maps with ArcGIS Online (or similar). Mappings resulted from GPR and UAV survey, statistical data generated by the natural studies on the selected perimeters will be corroborated with existing maps of the region in an interactive and intuitive manner.

The database will be developed to satisfy all the research fields' data types so that it could be easily overlapped with referenced maps (already existing or generated with the UAV) as intensity distribution maps of values, punctual values, observations, images and even 3D reconstructions.

Each monument will have a dedicated page with all the data collected from the database. The 3D reconstructions will be displayed in an embedded interactive area. Figure 7 depicts the user interface of this web embedded 3D viewing tool with a test of photogrammetry realized at one of the monuments, Fundătura. This is a result of 37 images taken at the eye level. During the proper investigation campaign this monument will be reconstructed from more than 500 images taken in a certain shooting strategy in order to capture all the cracks, niches and detailed inscriptions.

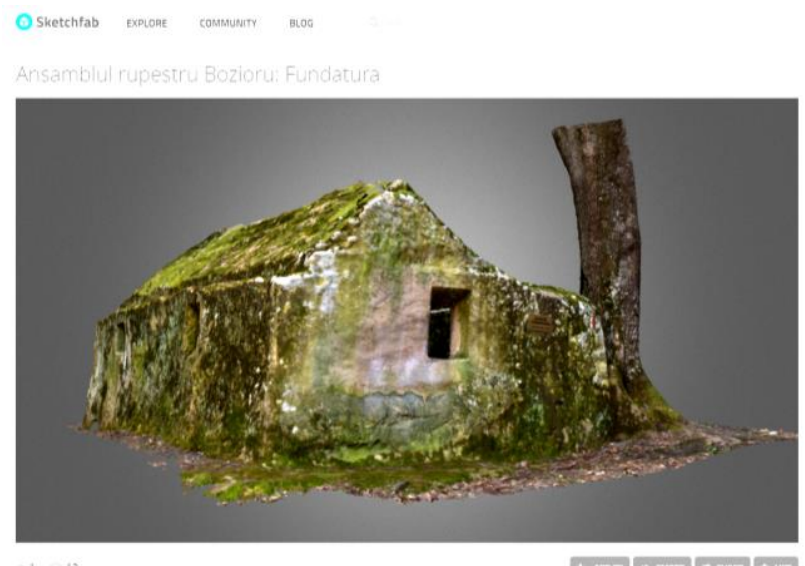

Figure 8 Photogrammetry test on Fundătura as viewed with Sketchfab

\section{CONCLUSIONS}

The resulted integrated research model will determine a new and coherent approach on the valorisation process of the cultural landscape by relating complex information from science of conservation with the study of natural environment.

Following the relation of interdependence between natural and cultural heritage (Lowenthal David, 1985, 2005) this project proposes an integrated approach that cancels the borders between cultural and natural heritage, in order to characterize and help to define the specificity of cultural landscape concept. The case studies selected for the demonstration, accurately reflects the necessity of this integrated research that will generate new knowledge, innovative perspectives for long time management and a certain protocol for advanced documentation and efficient conservation strategy.

\section{ACKNOWLEDGEMENTS}

This work has been realized within the Program Partnerships in Priority domains PN-III-P2-2.1-PED-2016-1407 ARTEMIS: Integrated digital platform for the valorisation of the cultural landscape from Buzau Mountains. Case Study: The Natural Environment and the historical monuments of the AlunișBozioru Area.

\section{REFERENCES}

Andrăşanu, A., 2008, Buzău Geopark. Building a new aspiring geopark. Proceedings of the 3rd International UNESCO Conference on Geoparks, Osnabrück, Germany: 15.

Constantin Buzdugan, 1976, Pumnale hallstattiene târzii de pe teritoriul României, Cercetări arheologice, vol.IV, Biblioteca Muzeologică, p. 264

Council of Europe , 2005, Council of Europe Framework Convention on the Value of Cultural Heritage for Society, Council of Europe Treaty Series, No. 199, Faro http://www.coe.int/en/web/conventions/full-list//conventions/rms/0900001680083746

LHM, 2014, List of historical monuments in Buzău County http://patrimoniu.gov.ro/ro/monumente-istorice/listamonumentelor-istorice

Lowenthal David, 1985, The Past is a Foreign Country, Cambridge University Press

Lowenthal David, 2005, Natural and Cultural Heritage, International Journal of Heritage Studies, Volume 11, Issue 1, p. $81-92$

Moldovan Adrian Septimiu, 2012, Wireless Polyvalent Equipment for Microclimate Conditions Monitoring, .P.B. Sci. Bull., Series A, Vol. 74, Iss. 1, pages: 171-182

Monica Simileanu, Walter Maracineanu, Joakim Striber, Cristian Deciu, Dragos Ene, Laurentiu Angheluta, Roxana Radvan, Roxana Savastru, 2008, Advanced Research Technology for Art and Archaeology - ART4ART mobile laboratory, Journal of Optoelectronics and Advanced Materials, vol 10 , no. 2 
Munteanu, D., Weber, P., Papadopol, A. - editors, 2002, Atlasul păsărilor clocitoare din România. Published by the Romanian Ornithological Society, 152 pp.

Mutihac, V., Stratulat, M.I. \& Fechet, R.M., 2004, Geologia României. Ed. Didactică și Pedagogică, Bucharest, 249 pp.

Roban, R.D., Andrăşanu, A. - editors, 2010, Sedimentology of Flysch and Molasses. Field Trip Guide Book, Geological Society of Romania, Faculty of Geology and Geophysics \& GeoEcoMar (publisher).

UNESCO World Heritage List, 1979, Rock-Hewn Churches of Ivanovo http://whc.unesco.org/en/list/45

WHC, 1992, World Heritage Convention http://whc.unesco.org/en/sessions/16COM/documents/

WCH, 2008, 32nd session of the World Heritage Committee, Quebec, Canada, Annex 3, p.86 